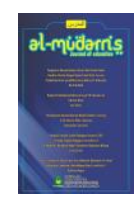

AL-MUDARRIS : journal of education, Vol. 2, No. 1 April 2019

Homepage

: http://e-journal.staima-alhikam.ac.id/index.php/al-mudarris

ISSN

: 2620-5831 (print), ISSN: 2620-4355(online)

DOI

: 10.32478/al-mudarris.v2i1.194

Article type

: Original Research Article

\title{
PENGEMBANGAN MEDIA PEMBELAJARAN BERBASIS ICT MENGGUNAKAN MACROMEDIA FLASH PADA MATA PELAJARAN IPA MI/SD
}

\author{
Aquami*1, Muhamad Afandi*2, Andi Putra Sairi*3 \\ PGMI,UIN Raden Fatah Palembang, Indonesia \\ 1aquami_uin@radenfatah.ac.id, \\ 2 muhammadafandi_uin@radenfatah.ac.id, \\ ${ }^{3}$ andiputrasairi_uin@ @radenfatah.ac.id
}

\begin{abstract}
The purpose of this reseach to describe the process of planning or designing, the level of practicality, and the effectiveness of applying ICT-based learning media using Macromedia Flash in class science subjects IV SD / MI. The method used in this study is research and development (R \& D) using a four-dimensional model (4-D) including the definition, design, development and dissemination stages. Data collection methods using interviews, observations, expert validation questionnaires and respondents' questionnaires, as well as tests of learning outcomes. Data analysis in this study uses percentage analysis. The results of this study are as follows: (1) The design or design of the media includes the cover page, media, program, material (text, videos, exercises) and tests. (2) The level of practical application very practical average with a total average score of 87.5 on the response of teachers and learners answers obtained Total score 154 with a total average of 90.58 classified as very practical. (3) Effective use of the media is very effective in achieving student learning outcomes. The results of votes accumulated three cognitive, emotional and psychomotor aspects obtained the number of 1423 and an average of 83.70 with both categories. In addition, from the data value of all learners who are known to have reached a value of scientific subjects of completeness at least $100 \%$ classified as very effective.
\end{abstract}

E-mail address: aquami_uin@radenfatah.ac.id,muhammadafandi_uin@ radenfatah.ac.id, andiputrasairi_uin@ radenfatah.ac.id 
AL-MUDARRIS:journal of education, Vol. 2. No. 1 April 2019, ISSN: 2620-5831 (print), ISSN: 2620-4355(online)

DOI: 10.32478/al-mudarris.v2i1.194

Keyword: Learning Media; ICT; Macromedia Flash; Science MI/SD

\begin{abstract}
Abstrak
Metode penelitian yang digunakan dalam penelitian ini adalah metode R\&D dengan model four-D (4-D. yang terdiri dari tahap pendefinisian, perancangan, pengembangan dan penyebaran. Metode pengumpulan data menggunakan observasi, wawancara, angket validasi ahli dan angket responden, dan tes hasil belajar. Analisis data pada penelitian ini menggunakan analisis persentase. Hasil penelitian ini antara lain: (1) Rancangan atau desain media terdiri dari halaman depan, tentang media, silabus, materi (teks, video, latihan), dan tes. (2) Tingkat kepraktisan penerapan media sangat praktis, dengan total rata-rata skor 87,5 pada respon guru dan respon peserta didik dengan total rata-rata skor 90,58 dengan kategori sangat praktis. (3) Efektivitas penerapan media sangat efektif dalam mencapai hasil belajar peserta didik, dari data nilai seluruh peserta didik yang berjumlah 17 telah mencapai nilai ketuntasan minimal mata pelajaran IPA sebesar $100 \%$ dengan kategori sangat efektif.
\end{abstract}

Kata kunci: Media pembelajaran, ICT, Macromedia Flash, IPA MI/SD

\title{
A. PENDAHULUAN
}

Arus informasi di saat sekarang ini semakin meningkat yang dibuktikan oleh perkembangan jaringanjaringan internet di seluruh dunia dan mengharuskan seseorang untuk mampu beradaptasi kalau tidak ingin tereliminasi dan ditinggalkan oleh zaman. Kondisi ini juga sudah berimbas pada dunia pendidikan khususnya proses pembelajaran baik dengan cepat ataupun lambat dan juga tidak akan dapat dilepaskan dari keberadaan alat bantu utama ICT (Information and Communication Technology) seperti komputer dan internet. Secara ilustratif dapat gambarkan di mana saat ini buku-buku dan alat tulis tidak 
AL-MUDARRIS:journal of education, Vol. 2. No. 1 April 2019, ISSN: 2620-5831 (print), ISSN: 2620-4355(online)

DOI:

berada lagi di tas anak sekolah, akan tetapi sudah digantikan dengan komputer, notebook, dan smartphone. Komputer, notebook, dan smartphone ini diakses menggunakan internet tanpa kabel yang isinya adalah materi-materi belajar yang dapat dibaca, dilihat dan didengar, serta dilengkapi dengan fitur-fitur lain seperti perekam suara dan kamera digital.

Keadaan seperti di atas menindikasikan bahwa semua perlengkapan anak sekolah di saat ini sudah modern yang dijadikan sebagai alat bantu belajar. Untuk itu model pembelajaran di sekolahpun harus mampu mengikuti perkembangan Teknologi Informasi dan Komunikasi. Salah satunya yaitu melalui pembelajaran berbasis media TIK atau ICT. Guru sebagai pelaksana proses pembelajaran harus mampu merancang, menggunakan, dan mengevaluasi media pembelajaran tersebut. TIK atau ICT bukanlah suatu teknologi yang dapat berdiri sendiri, akan tetapi ia merupakan gabungan dari beberapa hardware dan software. Poin penting yang wajid dan harus guru perhatikan dalam pemanfaatan ICT sebagai media pembelajaran adalah keterseidaan hardware dan software dan bentuk metode pembelajaran yang akan digunakan.

Penggunaan teknologi dalam kegiatan pembelajaran di kelas sesungguhnya mempunyai beberapa kelebihan, seperti kerja peserta didik (mengefisienkan) menjadi lebih cepat dan mudah serta menyenangkan karena adanya interaksi antara peserta didik dengan gambar, suara, warnawarna, video, dan sesuatu yang instan. Situasi dan kondisi seperti ini pada dasarnya merupakan faktor vital dan esensial untuk mencapai efektivitas belajar. ${ }^{1}$ Di sini teknologi mampu membangkitkan emosi positif dalam proses belajar. ${ }^{2}$ Penggunaan media pembelajaran

${ }^{1}$ A. Suryadi, Pemanfaatan ICT dalam Pembelajaran, Jurnal Pendidikan Terbuka dan Jarak Jauh, Volume 8, Nomor 1, Maret 2007, h. 92

${ }^{2}$ R. Zainiah dan T. Rijanto, Pengembangan Media Pembelajaran Berbasis Animasi dan Simulasi untuk Meningkatkan Hasil Belajar Peserta didik pada Mapel Instalasi Penerangan Listrik di SMKN 1 Sidoarjo, 2016, Volume 5, Nomor 2, h. 515-522. 
beroreintasi Teknologi Informasi di era sekarang sudah menjadi suatu keharusan. Walaupun dalam merancang media tersebut memerlukan keahlian khusus, namun bukan berarti untuk dihindari maupun untuk ditinggalkan. Media pembelajaran ICT yang dikembanglan dapat berupa animasi, smart phone, internet atau intranet, dan CD Room/Flash Disk di mana komponen utama yang digunakan meliputi Learning Management System (LMS), dan Learning Content (LC). ${ }^{3}$

Berdasarkan hasil wawancara dengan guru MI Assegaf Palembang diketahui bahwa, guru kelas IV di MI Assegaf saat sekarang ini masih minim dalam menggunakan media pembelajaran yang sifatnya terbarukan dan mengikuti perkembangan IPTEK seperti berbasis ICT di dalam kegiatan pembelajaran. Media pembelajaran yang sering digunakan guru adalah buku guru dan buku peserta didik yang diterbitkan oleh Kemendikbud. Guru seringkali hanya menggunakan buku sebagai media pembelajaran utama dalam menyampaikan materi pembelajaran. Walaupun sebenarnya peralatan seperti LCD atau proyektor sudah dimiliki madarasah. Guru masih belum memanfaatkan peralatan yang bisa mendukung ICT dalam pembelajaran. $^{4}$

Berdasarkan hasil observasi pada pembelajaran IPA menunjukkan bahwa, peserta didik kelas IV MI Assegaf Palembang dalam pembelajaran cenderung pasif, monoton, cepat bosan, dan kurang memperhatikan guru karena pembelajaran yang dilaksanakan cenderung berpusat kepada guru. Guru tidak menggunakan media pembelajaran yang inovatif dan bervariatif. Hal ini juga menjadi pemicu munculnya sikap-sikap negatif peserta didik tersebut dalam pembelajaran. Peserta didik jadi kurang terfokus

${ }^{3}$ A. Muhson, Pengembangan Media Pembelajaran Berbasis Teknologi Informasi. Jurnal Pendidikan Akuntansi Indonesia, 2010, Volume 8, Nomor 2, h. 1-10

${ }^{4}$ Hasil Fokus Group Discussion dengan guru kelas IV MI Assegaf Palembang, Dosen, dan Mahasiswa PGMI, Selasa 14 Agustus 2018 
AL-MUDARRIS:journal of education, Vol. 2. No. 1 April 2019, ISSN: 2620-5831 (print), ISSN: 2620-4355(online)

DOI:

perhatiannya, minat dan motivasi peserta didik juga kurang dan pada akhirnya peserta didik tidak maksimal dalam menguasai materi pembelajaran. ${ }^{5}$

Pendidikan Sains (IPA) adalah salah satu program pendidikan yang erat hubungannya dengan tata cara mengetahui dan mengenal alam semesta dan menjadi mata pelajaran yang penting untuk para peserta didik di antara mata pelajaran lainnya dalam mengenali diri sendiri dan alam di sekitarnya. Sehingga peserta didik mampu mengembangkan pengetahuan dan pemahaman IPA dalam kehidupan sehari-hari, mengembangkan kesadaran betapa pentingnya memelihara dan menjaga serta melestarikan alam dan dapat mengembangkan keterampilan dalam menyelidiki alam serta memecahkan masalah-masalah yang berkaitan dengan alam semesta ini. Oleh sebab itu, diperlukan pembelajaran yang optimal dilaksanakan sehingga keefektifan dalam proses belajar mengajar yang menjadi acuan penting dalam medidik peserta didik menjadi lebih baik dan tujuan yang ingin dicapai dapat diwujudkan.

Penerapan TIK/ICT dalam pembelajaran IPA dapat membantu guru untuk lebih mengefisienkan metode pembelajaran yang diterapkan khususnya dalam penyampaian materi yang membutuhkan penjelasan proses yang lebih jelas dan secara nyata. Kurangnya minat belajar biasanya dikarenakan kurangnya fasilitas dalam proses pembelajaran, yang mengakibatkan kurangnya pemahaman dalam proses belajar mengajar yang dilakukan di sekolah. Adanya media pembelajaran berbasis TIK/ICT dapat menjadi daya tarik serta membuat sebuah ikatan dalam proses pembelajaran antara guru dengan peserta didik lebih harmonis. ${ }^{6}$ Pemilihan bahan ajar seperti media yang digunakan sebagai langkah dan cara untuk meningkatkan

${ }^{5}$ Hasil Fokus Group Discussion dengan guru kelas IV MI Assegaf Palembang, Dosen, dan Mahasiswa PGMI, Selasa 14 Agustus 2018

${ }^{6}$ A. Z. Rahman, T. N. Hidayat, dan I. Yanuttama, Media Pembelajaran IPA Kelas 3 Sekolah Dasar Menggunakan Teknologi Augmented Reality Berbasis Android.Seminar Nasional Teknologi Informasi dan Multimedia, 2017, Volume 5, Nomor 1, h. 43-48 
AL-MUDARRIS:journal of education, Vol. 2. No. 1 April 2019, ISSN: 2620-5831 (print), ISSN: 2620-4355(online)

DOI: 10.32478/al-mudarris.v2i1.194

beberapa kemampuan seperti salah satunya kemampuan berpikir kritis peserta didik. Selanjutnya kegiatan pembelajaran IPA dapat dilakukan dengan menggunakan media yang lebih konkret dan kontekstual yang dapat meningkatkan kemampuan peserta didik dalam berpikir kritis pada pembelajaran IPA. ${ }^{7}$ Untuk itu peran media pembelajaran berbasis ICT sangat penting dalam pembelajaran IPA di MI/SD. Selain itu kompetensi pendidik juga harus menjadi poin penting karena kompetensi pendidik yang paling utama yang harus ada pada diri pendidik adalah komptensi personal dan social. ${ }^{8}$

Berdasarkan pemaparan di atas, maka peneliti merencanakan solusi pembelajaran yang diharapkan dapat meningkatkan minat dan hasil belajar peserta didik. Model pembelajaran yang digunakan yaitu penggunaan media pembelajaran berbasis ICT seperti komputer yang merupakan salah satu alat telekomunikasi dan informasi yang mengikuti perkembangan zaman dalam era globalisasi saat ini. Hal ini sesuai dengan mata pelajaran IPA yang selalu mengikuti perkembangan zaman. Abad ke 21 ditandai dengan begitu cepat dan pesatnya perkembangan sains dan teknologi dalam semua starata kehidupan masyarakat, salah satunya teknologi informasi dan komunikasi. Oleh sebab itu, diperlukan berbagai cara dalam pembelajaran yang mampu mempersiapkan peserta didik agar memahami Sains/IPA dan teknologi, mampu berfikir kritis , logis, dan kreatif serta mampu berargumentasi secara

\footnotetext{
${ }^{7}$ T. Aprilia, Sunardi, dan Djono, Pemanfaatan Media Buku Digital Berbasis Kontekstual dalam Pembelajaran IPA dalam "Pemanfaatan Smartphone untuk Literasi Produktif Menjadi Guru Hebat dengan Smartphone", Pascasarjana Teknologi Pendidikan FKIP Universitas Sebelas, Maret, 2017, h. 195-206

8 Yulianto, 'KONSEP PENDIDIKAN ANAK DALAM PERSPEKTIF IBNU HAJAR AL- HAITAMI (Ragam Eksplorasi Kitab Tahrīru Al-Maqōl F̄̄ Adābi Wa Ahkāmi Wa Fawā'idu Yahtāju Ilaihā Mu’addibū Al-Ațfāl)', AL-MUDARRIS: Journal of Education, 1.1 (2018), 39-54 <https://doi.org/http://dx.doi.org/10.32478/almudarris.v1i1.98>.
} 
AL-MUDARRIS:journal of education, Vol. 2. No. 1 April 2019, ISSN: 2620-5831 (print), ISSN: 2620-4355(online)

DOI:

tepat dan benar. ${ }^{9}$ Tujuan dari penelitian ini adalah untuk mendeskripsikan proses perancangan atau desain media pembelajaran berbasis ICT menggunakan macromedia flash pada mata pelajaran IPA Kelas IV SD/MI, untuk mendeskripsikan tingkat kepraktisan penerapan media pembelajaran berbasis ICT menggunakan macromedia flash pada mata pelajaran IPA Kelas IV SD/MI, dan untuk mendeskripsikan tingkat efektifitas penerapan media pembelajaran berbasis ICT menggunakan macromedia flash pada mata pelajaran IPA Kelas IV SD/MI.

\section{B. METODE PENELITIAN}

Penelitian dan pengembangan (Research and Development) merupakan jenis penelitian yang digunakan dalam penelitian ini. Penelitian dan pengembangan adalah metode penelitian yang digunakan untuk menghasilkan suatun produk tertentu dan menguji keefektifan dari produk tersebut. ${ }^{10}$ Kegiatan penelitian dilakukan untuk mendapatkan beberapa informasi tentang kebutuhan apa saja yang diperlukan oleh pengguna, sedangkan kegiatan pengembangan dilakukan untuk menghasilkan produk berupa media pembelajaran. Kegiatan penelitian ini tidak hanya dilakukan pada tahap pengumpulan informasi pengguna tetapi juga pada proses pengembangan media pembelajaran, di mana kegiatan ini membutuhkan kegiatan dalam pengumpulan data dan analisis data, seperti tahap proses validasi oleh pakar dan juga pada tahap validasi empiris. Sedangkan kegiatan pengembangan mengacu pada produk yang dihasilkan yaitu berupa media pembelajaran IPA MI/SD berbasis ICT menggunakan mcromedia flash. Secara umum penelitian ini bertujuan untuk mengukur efektifitas dan kepraktisan penerapan media pembelajaran berbasis ICT program macromedia flash pada pembelajaran IPA di Kelas IV MI/SD. Model pengembangan yang

${ }^{9}$ Trianto, Model Pembelajaran Terpadu, Jakarta, Bumi Aksara, 2010, h. 154

${ }^{10}$ Sugiyono, Metode Penelitian Pendidikan Pendekatan Kuantitatif, Kualitatif, dan R\&D, Bandung, Alfabeta, 2008, h. 407 
AL-MUDARRIS:journal of education, Vol. 2. No. 1 April 2019, ISSN: 2620-5831 (print), ISSN: 2620-4355(online)

DOI: 10.32478/al-mudarris.v2i1.194

digunakan yaitu four-D (4-D) models yang terdiri dari tahap pendefinisian (define), perancangan (design), pengembangan (develop) dan penyebaran (disseminate). Pada penelitian ini dibatasi hanya pada tahap pengembangan karena keterbatasan waktu dan biaya penelitian. $^{11}$

\section{HASIL PENELITIAN}

\section{Tahap Pendefinisian}

Pada tahap pendefinisian ini dilakukan dengan menganalisis kompetensi pembelajaran, karakteristik peserta didik, dan ruang lingkup materi pelajaran IPA MI/SD yang akan diajarkan oleh guru berdasarkan kurikulum 2013. Tahapan ini meliputi 3 langkah kegiatan yaitu analisis kurikulum, analisis materi, dan analisis peserta didik.

Kurikulum yang digunakan dalam pembelajaran IPA kelas IV MI/SD ini adalah kurikulum 2013 dengan pendekatan tematik integratif. Pendekatan tematik integratif merupakan pendekatan yang memadukan beberapa mata pelajaran dengan tema yang sama. Kemudian juga disebutkan bahwa pembelajaran tematik merupakan suatu model pendekatan pembelajaran terpadu (integrated learning) pada tingkat atau jenjang TK/RA atau sekolah dasar (SD/MI) berdasarkan kepada tema-tema tertentu yang sifatnya lebih kontekstual dengan dunia mereka ${ }^{12}$. Berdasarkan pendekatan tersebut maka pembelajaran mata pelajaran IPA akan dilaksanakan dengan memadukan mata pelajaran-mata pelajaran lain berdasarkan tema yang sama dalam satu kegiatan pembelajaran.

Kegiatan pada tahap analisis materi dilakukan dengan menganalisis kurikulum 2013, kompetensi inti, tema dan

${ }^{11}$ Trianto, Mendesain Model Pembelajaran Inovatif-Progresif: Konsep, Landasan, dan Implementasinya pada Kurikulum Tingkat Satuan Pendidikan (KTSP), Jakarta, Kencana Prenada Media Group, 2010, h. 189; Trianto, Model Pembelajaran Terpadu dalam Teori dan Praktek, Jakarta, Prestasi Pustaka, 2007, h. 65

${ }^{12}$ Andi Prastowo, Pengembangan Bahan Ajar Tematik Tinjauan Teoretis dan Praktik, Jakarta, Kencana, 2014, h.52 
AL-MUDARRIS:journal of education, Vol. 2. No. 1 April 2019, ISSN: 2620-5831 (print), ISSN: 2620-4355(online)

DOI:

sub tema, kemudian melakukan pemetaan kompetensi seperti kompetensi dasar, tujuan pembelajaran,dan materi pembelajaran. Pemilihan materi pada kegiatan ini dilakukan dengan memperhatikan berbagai pertimbangan sebagai upaya agar materi yang dipilih seyogyanya dapat menunjang pencapaian kompetensi inti dan kompetensi dasar. Terdapat enam pertimbangan yang yang dilakukan dalam pemilihan materi dua diantaranya adalah relevansi dengan kebutuhan siswa dan lingkungan serta alokasi waktu yang tersedia. ${ }^{13}$ Materi yang dikembangkan dalam media pembelajaran IPA berbasis ICT menggunakan macromedia flash ini adalah materi tema 2 "Selalu Berhemat Energi" dan sub tema 1 "Sumber Energi" yang diajarkan ke dalam 6 kegiatan pembelajaran.

Tujuan mengnalisis peserta didik dilakukan untuk mengetahui karakteristik peserta didik kelas IV dalam pembelajaran sebagai pertimbangan dalam mengembangkan media pembelajaran IPA berbasis ICT menggunakan macromedia flash. Analisis ini perlu dilakukan karena dari peserta didik dapat diketahui beberapa informasi atau permasalahan yang terjadi sebelumnya. Informasi atau permasalahan tersebut dapat berupa bagaimana pengetahuan mereka tentang kurikulum, sejauh mana pengetahuan dan pemahaman mereka tentang materi, seperti apa masalah yang terjadi atau dialami dalam pembelajaran, dan harapan mereka dalam kegiatan pembelajaran ${ }^{14}$.

Berdasarkan data yang telah diperoleh dapat dikemukakan bahwa karakteristik peserta didik kelas IV dalam pembelajaran cenderung pasif, monoton, cepat bosan, dan kurang memperhatikan guru karena pembelajaran yang dilaksanakan cenderung berpusat kepada guru. Melalui penggunaan media pembelajaran IPA berbasis ICT menggunakan macromedia flash yang akan dikembangkan diharapkan iklim belajar di dalam kelas bisa lebih aktif,

${ }^{13}$ Andi Prastowo, Op. Cit., h.265

${ }^{14}$ Wina Sanjaya, Perencanaan dan Desain Sistem Pembelajaran, Jakarta, Prenadamedia Group, 2008, h.10 
efektif, inovatif, dan menyenangkan sehingga tujuan pembelajaran dapat tercapai.

\section{Tahap Perancangan}

Tahap perancangan merupakan merupakan tahap merancang desain produk awal pengembangan media pembelajaran IPA berbasis ICT menggunakan macromedia flash. Tahap perancangan tersebut yaitu mendesain blok diagram yang ditunjukkan seperti pada gambar 1 .

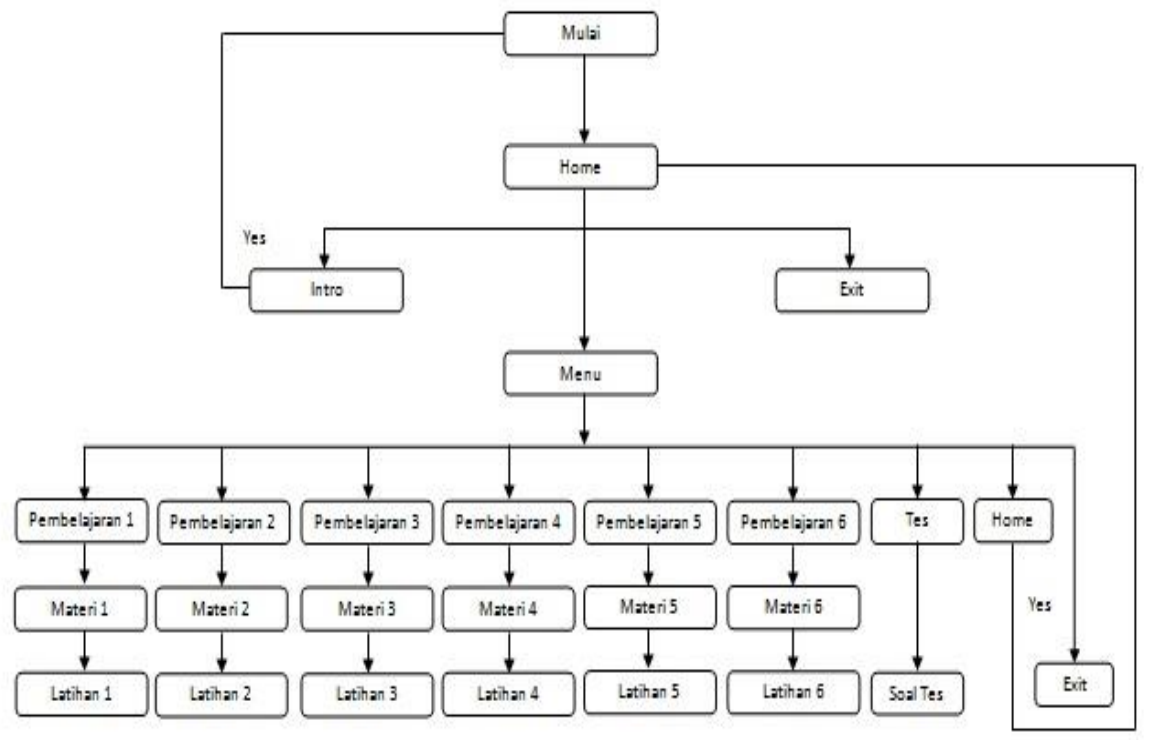

Gambar 1. Desain Blok Diagram

Tahap perancangan berikutnya adalah merancang layout dan story board, mengumpulkan materi pembelajaran pada tema 2 yaitu selalu berhemat energi sub tema 1 sumber energi baik berupa image, sound, video, animasi, dan lain-lain, menentukan sistem operasi media pembelajaran IPA berbasis ICT yang dikembangkan, menentukan program macromedia flash yang digunakan dalam pengembangan media pembelajaran IPA berbasis ICT, dan menentukan aplikasi yang cocok untuk digunakan untuk pengembangan media pembelajaran IPA berbasis ICT. Setelah komponen-komponen media di rancang maka dilakukan pembuatan media pembelajaran IPA berbasis ICT yang terdiri dari beberapa bagian utama. Bagian tersebut 
DOI:

meliputi halaman depan, tentang media, silabus, materi, dan latihan.

Halaman depan merupakan halaman awal yang berisi informasi media secara umum seperti kalimat "Selamat Datang" dan ditampilkan ketika file dalam format .exe dibuka. Halaman berikutnya yaitu halaman tentang media. Tentang media berisi tentang informasi media pembelajaran secara lebih menyuluruh baik dalam segi jenis media maupun informasi terkait cara menggunakan media pembelajaran ini. Halaman ketiga dalam media pembelajaran ini yaitu halaman silabus. Pada halam silabus disajikan informasi-informasi tentang kompetensikompetensi yang harus dimiliki oleh peserta didik seperti kompetensi inti dan kompetensi dasar. Halaman keempat adalah halaman materi. Halaman materi merupakan halaman yang paling dominan pada media Pembelajaran Berbasis ICT Menggunakan Macromedia Flash pada Mata Pelajaran IPA Kelas IV SD/MI ini. Terdapat enam halaman materi yang masing-masing disebut dengan pembelajaran I, II, III, IV, V, dan VI. Halaman terakhir pada media yang dikembangkan adalah halaman latihan. Sedikit berbeda dengan halaman latihan pada setiap pembelajaran, halaman latihan khusus yang ada pada halaman terkahir merupakan latihan dari semua pembelajaran pada sub tema 2 tentang "Hemat Energi". Pada halaman ini, penulis membuat soal masih dalam bentuk soal tes pilihan berganda dengan jumlah soal 10 item. Gambaran dari desain halaman media Pembelajaran Berbasis ICT menggunakan macromedia flash pada mata pelajaran IPA kelas IV SD/MI dapat dilihat pada gambar 2 . 
AL-MUDARRIS:journal of education, Vol. 2. No. 1 April 2019, ISSN: 2620-5831 (print), ISSN: 2620-4355(online)

DOI: 10.32478/al-mudarris.v2i1.194

\section{Selamat Datang}

Media Pembelajaran

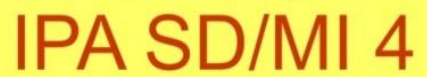

Kurikulum 2013

Sub Tema 1 "Sumber Energi"

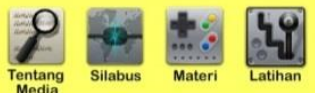

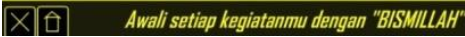

(a)

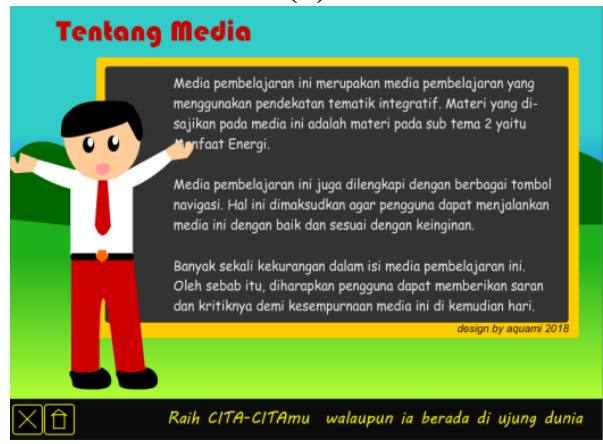

(b)

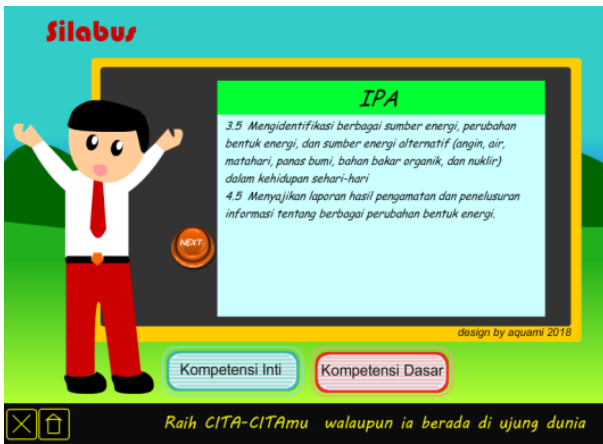

(c) 
AL-MUDARRIS:journal of education, Vol. 2. No. 1 April 2019, ISSN: 2620-5831 (print), ISSN: 2620-4355(online)

DOI:

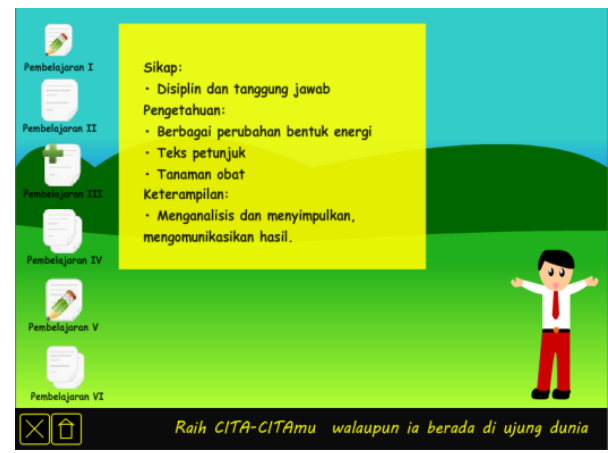

(d)

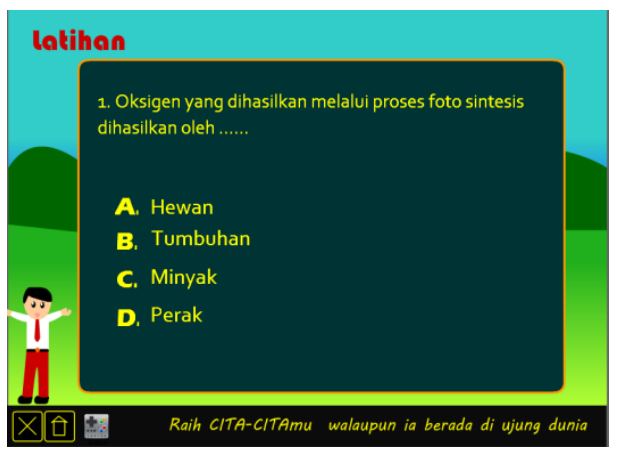

(e)

Gambar 2. Halaman media (a) Depan, (b) Tentang Media, (c) Silabus

(d) Materi, (e) Latihan

Pada halaman materi terdapat beberapa komponen yang menyusun satu buah materi pada masing-masing pembelajaran. Komponen penyusun ini berbentuk teks/bacaan, video, dan disetiap akhir pembelajaran juga terdapat latihan dalam bentuk soal pilihan ganda seperti pada gambar 3 . 
AL-MUDARRIS:journal of education, Vol. 2. No. 1 April 2019, ISSN: 2620-5831 (print), ISSN: 2620-4355(online)

DOI: 10.32478/al-mudarris.v2i1.194

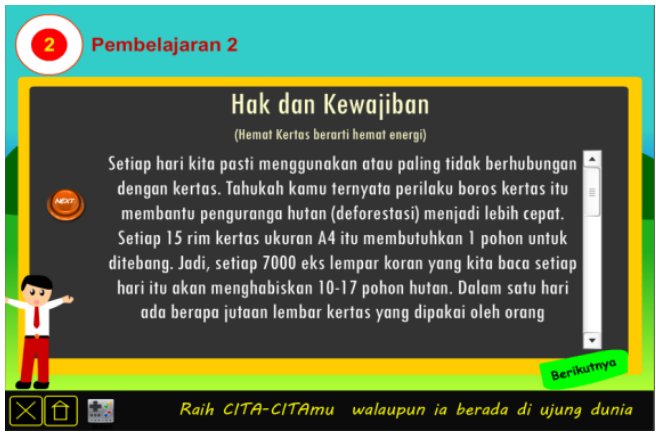

(a)

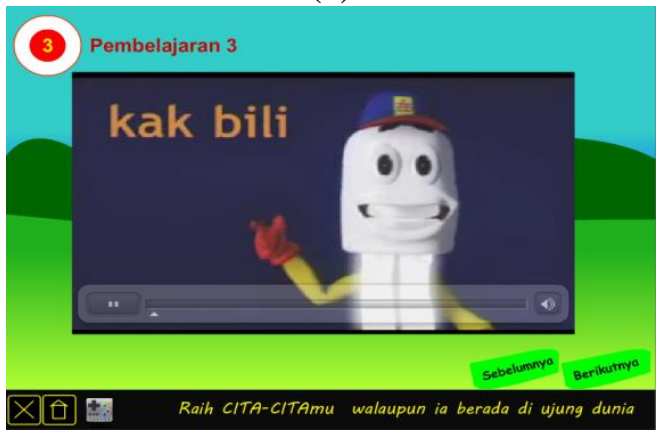

(b)

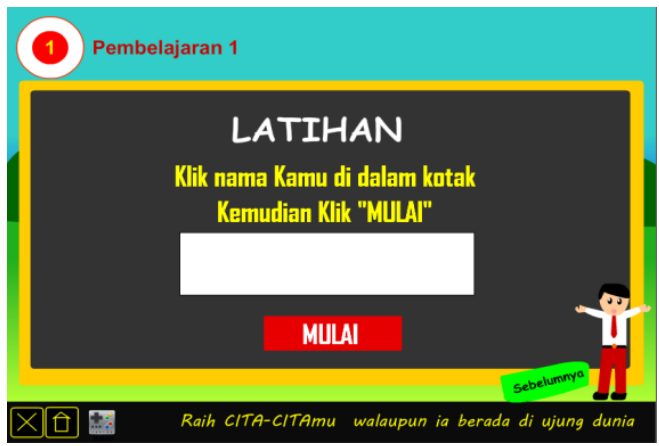

(c)

Gambar 3. Halaman Materi dalam Bentuk (a) Teks/Bacaan, (b) Video, (c) Latihan

\section{Tahap Pengembangan}

Tahap pengembangan merupakan tahap ketiga dalam penelitian dan pengembangan ini. Tahap pengembangan ini meliputi kegiatan uji validitas produk, kepraktisan produk, dan efektifitas produk. Terdapat dua macam validasi yang digunakan pada pengembangan media pembelajaran IPA 
DOI:

berbasis ICT menggunakan macromedia flash ini yakni validasi isi dan validasi konstruk. Tujuan melakuakan validasi isi yaitu untuk melihat apakah materi pada media yang dikembangkan sesuai dengan kompetensi inti, kompetensi dasar, indikator atau tujuan pembelajaran dalam kurikulum 2013. Kemudian tujuan dari validasi konstruk yaitu menentukan kesesuaian antara komponen-komponen media yang dikembangkan dengan unsur-unsur pengembangan yang sudah ditetapkan.

Tingkatan baik buruknya validitas isi dan konstruk pada media pembelajaran yang dikembangkan dapat dilakukan dengan cara teoritis dan empiris. Secara teoritis, tingkat validitas isi dan konstruks dikaji melalui penilaian yang berikan oleh ahli atau pakar yang disebut sebagai validator. Tujuannya yaitu untuk menilai kesesuaian setiap butir instrument yang diukurnya. Kemudian secara empiris, tigkat validitas isi dan konstruk dilakukan dengan cara memvalidasi hasil produk untuk mengukur tingkat ketepatan data dan ketelitiannya. Tahap validasi pengembangan media ini dimulai dengan analisis pendahuluan dan penilaian yang dilakukan oleh 3 orang pakar atau ahli yaitu ahli materi, ahli media, dan ahli bahasa.

1)

Validasi ahli materi

Validasi ahli materi dinilai oleh dosen yang ahli di bidang pendidikan atau pembelajaran di SD/MI. Tujuannya adalah untuk mengetahui kesesuaian materi dalam media pembelajaran yang dikembangkan dengan kompetensi inti, kompetensi dasar, indikator atau tujuan pembelajaran IPA kelas IV MI/SD dalam kurikulum 2013. Validasi materi dilaksanakan pada tanggal 15 Agustus 2018. Aspek yang dinilai dalam angket ahli materi ini terdiri dari aspek pendahuluan, isi, pembelajaran, dan latihan atau evaluasi. Hasil validasi materi dapat dilihat pada tabel 1 dan gambar 4. 
AL-MUDARRIS:journal of education, Vol. 2. No. 1 April 2019, ISSN: 2620-5831 (print), ISSN: 2620-4355(online)

DOI: 10.32478/al-mudarris.v2i1.194

Tabel 1. Hasil Angket Ahli Materi

\begin{tabular}{lccc}
\hline \multicolumn{1}{c}{ Aspek } & $\begin{array}{c}\text { Jumlah } \\
\text { Skor }\end{array}$ & Rata-rata & $\begin{array}{c}\text { Tingkat } \\
\text { Kevalidan }\end{array}$ \\
Pendahuluan & 10 & 83,33 & Sangat valid \\
Isi & 14 & 87,5 & Sangat valid \\
Pembelajaran & 32 & 88,88 & Sangat valid \\
Latihan atau & 14 & 87,5 & Sangat valid \\
tes & & & Sangat \\
$\quad$ Total & $\mathbf{7 0}$ & $\mathbf{8 7 , 5}$ & valid \\
\hline
\end{tabular}

\section{Hasil Angket Ahli Materi}

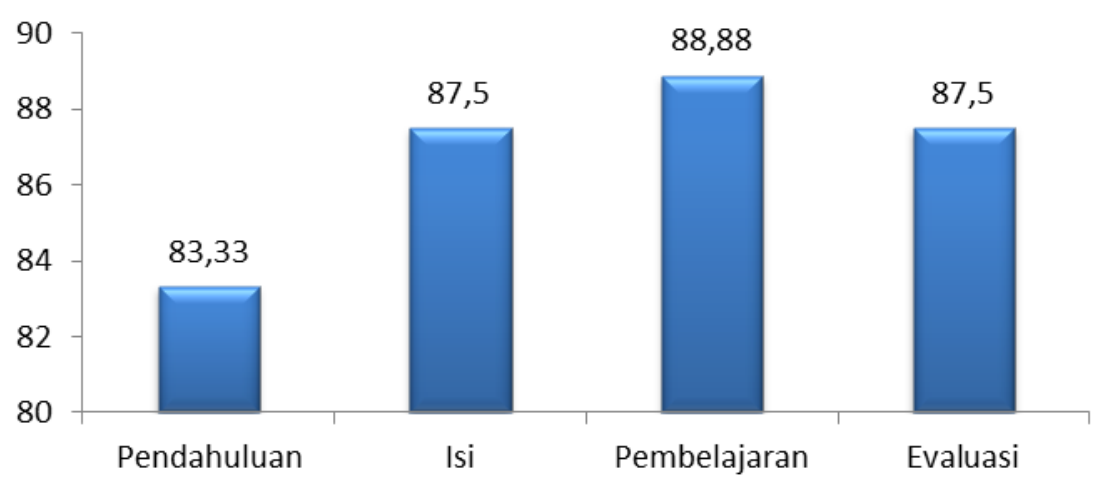

Gambar 4. Hasil Angket Ahli Materi

Dari data tersebut dapat dijelaskan di mana aspek pembelajaran mendapatkan rata-rata skor tertingi, sedangkan aspek pendahuluan mendapatkan skor terendah. Berdasarkan hasil angket ahli materi tersebut dapat disimpulkan bahwa materi dalam pengembangan media pembelajaran berbasis ICT menggunakan macromedia flash pada mata pelajaran IPA Kelas IV SD/MI pada kategori sangat valid dan dapat dilanjutkan pada uji coba lapangan.

2) Validasi ahli media

Validasi ahli media dinilai oleh dosen ahli pada bidang Teknologi Informasi dan Komunikasi (TIK). Tujuannya adalah untuk mengetahui kualitas dari produk 


\section{DOI:}

media yang dikembangkan baik dari segi tampilan, daya tarik, dan sebagainya. Validasi media dilaksanakan pada tanggal 22 Agustus 2018. Aspek yang dinilai dalam angket ahli medi ini terdiri dari aspek tampilan, penggunaan, dan pemanfaatan. Hasil validasi media dapat dilihat pada table 2 dan gambar 5.

Tabel 2. Hasil Angket Ahli Media

\begin{tabular}{cccc}
\hline Aspek & $\begin{array}{c}\text { Jumlah } \\
\text { Skor }\end{array}$ & $\begin{array}{c}\text { Rata- } \\
\text { rata }\end{array}$ & $\begin{array}{c}\text { Tingkat } \\
\text { Kevalida } \\
\mathbf{n}\end{array}$ \\
Tampilan & 35 & 87,5 & $\begin{array}{c}\text { Sangat } \\
\text { Valid } \\
\text { Sangat } \\
\text { Valid } \\
\text { Penggunaan }\end{array}$ \\
Pemanfaatan & 18 & 90 & $\begin{array}{c}\text { Sangat } \\
\text { Valid } \\
\text { Sangat } \\
\text { Valid }\end{array}$ \\
\hline
\end{tabular}

\section{Hasil Angket Ahli Media}

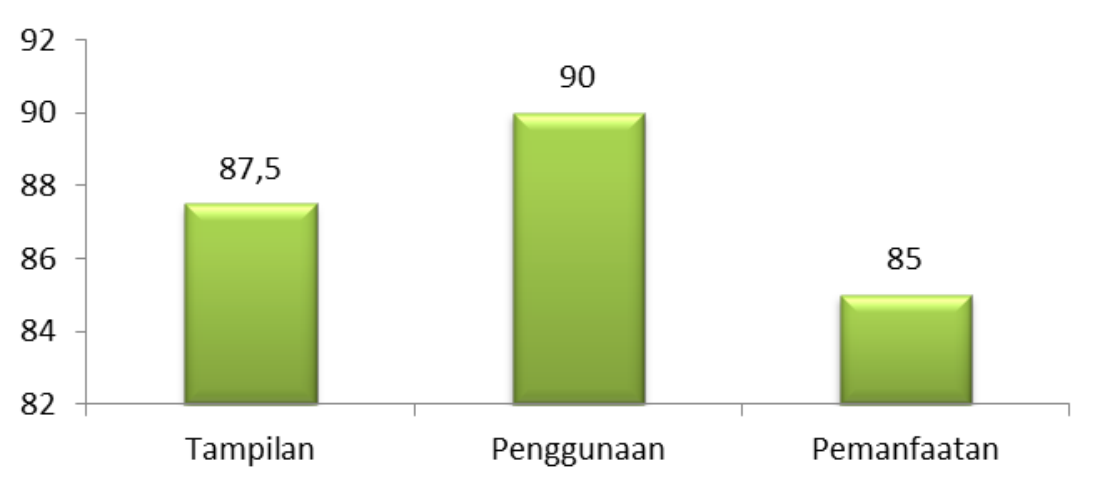

Gambar 5. Hasil Angket Ahli Media

Dari data tersebut dapat dijelaskan bahwa aspek penggunaan mendapatkan rata-rata skor tertingi, sedangkan aspek pemanfaatan mendapatkan skor terendah. Berdasarkan hasil angket ahli materi tersebut dapat 
AL-MUDARRIS:journal of education, Vol. 2. No. 1 April 2019, ISSN: 2620-5831 (print), ISSN: 2620-4355(online)

DOI: 10.32478/al-mudarris.v2i1.194

disimpulkan bahwa media dalam pengembangan media pembelajaran berbasis ICT menggunakan macromedia flash pada mata pelajaran IPA Kelas IV SD/MI pada kategori sangat valid dan dapat dilanjutkan pada uji coba lapangan.

3) Validasi ahli bahasa

Validasi aspek bahasa dilakukan oleh dosen ahli di bidang bahasa Indonesia. Tujuannya adalah untuk mendapatkan penilaian, masukan dan komentar tentang kesesuaian bahasa yang digunakan dalam produk media pembelajaran yang dikembangkan dengan karakteristik peserta didik kelas IV MI/SD yang akan diajar. Aspek yang dinilai dalam angket ahli bahasa ini terdiri dari aspek kesesuaian bahasa dengan perkembangan dari peserta didik, komunikatif, dan dialogis serta interaktif. Selain itu aspek koherensi dan keruntutan alur pikir, kesesuaian dengan kaidah bahasa Indonesia yang benar, dan penggunaan istilah dengan simbol atau lambang juga menjadi indkator dari penilaian validasi bahasa ini. Hasil validasi bahasa dapat dilihat pada table 3 dan gambar 6 .

Tabel 3. Hasil Angket Ahli Bahasa

\begin{tabular}{|c|c|c|c|}
\hline Aspek & Jumlah Skor & Rata-rata & Tingkat Kevalidan \\
\hline $\begin{array}{l}\text { Kesesuaian bahasa dengan } \\
\text { perkembangan peserta } \\
\text { didik }\end{array}$ & 8 & 100 & Sangat valid \\
\hline Komunikatif & 7 & 87,5 & Sangat valid \\
\hline Dialogis dan interaktif & 8 & 100 & Sangat valid \\
\hline $\begin{array}{l}\text { Koherensi dan keruntutan } \\
\text { alur pikir }\end{array}$ & 7 & 87,5 & Sangat valid \\
\hline $\begin{array}{l}\text { Kesesuaian dengan kaidah } \\
\text { bahasa Indonesia yang } \\
\text { benar }\end{array}$ & 8 & 100 & Sangat valid \\
\hline $\begin{array}{l}\text { Penggunaan istilah dengan } \\
\text { simbol atau lambang }\end{array}$ & 8 & 100 & Sangat valid \\
\hline Total & 46 & $\mathbf{9 5 , 8 3}$ & Sangat valid \\
\hline
\end{tabular}




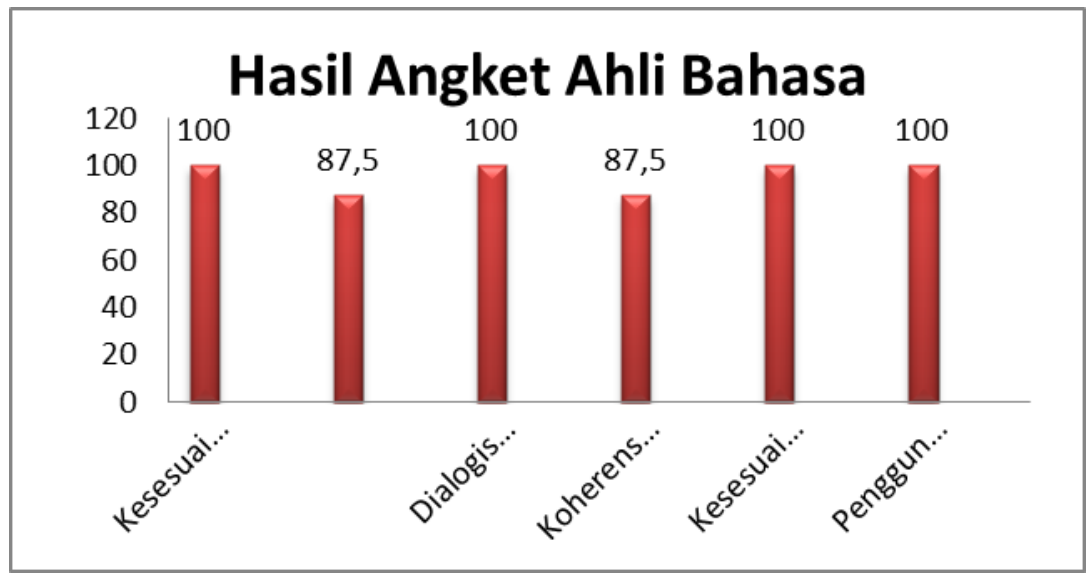

Gambar 6. Hasil Angket Ahli Bahasa

Data tabel 3 dan gambar di atas menunjukkan bahwa terdapat 4 buah aspek validasi bahasa yang mendapatkan rata-rata skor tertingi dan 2 aspek mendapatkan skor terendah. Kedua aspek tersebut yaitu aspek komunikatif dan aspek koherensi dan keruntutan alur pikir. Atas dasar ini dapat dikatakan bahwa hasil angket ahli pada pengembangan media pembelajaran berbasis ICT menggunakan macromedia flash pada mata pelajaran IPA Kelas IV SD/MI pada kategori sangat valid dan dapat dilanjutkan pada uji coba lapangan.

\section{Tahap Penyebaran}

1. Uji kepraktisan

Uji kepraktisan adalah uji tingkat keterpakaian media pembelajaran oleh guru dan peserta didik, yaitu dengan melaksanakan eksperimen pengajaran dengan menggunakan media pembelajaran yang telah diperbaiki dan dinilai valid oleh validator. Uji kepraktisan ini dilakukan dengan memberikan angket kepada guru dan peserta didik yang bertujuan untuk mengetahui bagaimana respon guru dan respon peserta didik setelah menggunakan media pembelajaran ini dalam proses pembelajaran. Hasil angket tersebut dapat dilihat pada tabel 4 dan gambar 7 . 
AL-MUDARRIS:journal of education, Vol. 2. No. 1 April 2019, ISSN: 2620-5831 (print), ISSN: 2620-4355(online)

DOI: 10.32478/al-mudarris.v2i1.194

Tabel 4. Hasil Angket Respon Guru

\begin{tabular}{|c|c|c|c|}
\hline Aspek & Jumlah Skor & Rata-rata & Tingkat Keprak \\
\hline Pembelajaran & 38 & 86,36 & Sangat prakti \\
\hline Tampilan & 21 & 87,5 & Sangat prakti \\
\hline Pemograman & 11 & 91,66 & Sangat prakti \\
\hline Total & 70 & 87,5 & Sangat prakt \\
\hline & Hasil Ang & t Respo & Suru \\
\hline 94 & & & 91,66 \\
\hline 90 & & & \\
\hline 88 & 86,36 & 87,5 & \\
\hline 86 & & & \\
\hline 84 & & & \\
\hline & Pembelajaran & Tampilan & Pemograman \\
\hline
\end{tabular}

Gambar 7. Hasil Angket Respon Guru

Dari data ini dapat dinyatakan bahwa aspek pemograman mendapatkan rata-rata skor tertinggi, sedangkan aspek pembelajaran mendapatkan skor terendah. Berdasarkan hasil angket respon guru tersebut dapat disimpulkan bahwa media pembelajaran berbasis ICT menggunakan macromedia flash pada mata pelajaran IPA Kelas IV SD/MI sangat praktis.

Kemudian angket responden peserta didik diberikan kepada peserta didik kelas IV MI Assegaf sejumlah 17 orang. Angket tersebut diberikan setelah peserta didik mengikuti kegiatan pembelajaran IPA di kelas IV MI Assegaf Palembang menggunakan media yang dikembangkan. Hasil angket tersebut dapat dilihat pada tabel 5 dan gambar 8. 
AL-MUDARRIS:journal of education, Vol. 2. No. 1 April 2019, ISSN: 2620-5831 (print), ISSN: 2620-4355(online)

DOI:

Tabel 5. Hasil Angket Responden Peserta Didik Tiap Aspek

\begin{tabular}{|c|c|c|c|}
\hline Aspek & $\begin{array}{c}\text { Jumlah } \\
\text { Skor }\end{array}$ & $\begin{array}{l}\text { Rata- } \\
\text { rata }\end{array}$ & $\begin{array}{c}\text { Tingkat } \\
\text { Kepraktisan }\end{array}$ \\
\hline Pembelajaran & 63 & 92 & Sangat praktis \\
\hline Tampilan & 57 & 83 & Sangat praktis \\
\hline Pemograman & 34 & 100 & Sangat praktis \\
\hline Total & 154 & 90,58 & $\begin{array}{l}\text { Sangat } \\
\text { praktis }\end{array}$ \\
\hline
\end{tabular}

\section{Hasil Angket Respon Peserta Didik}

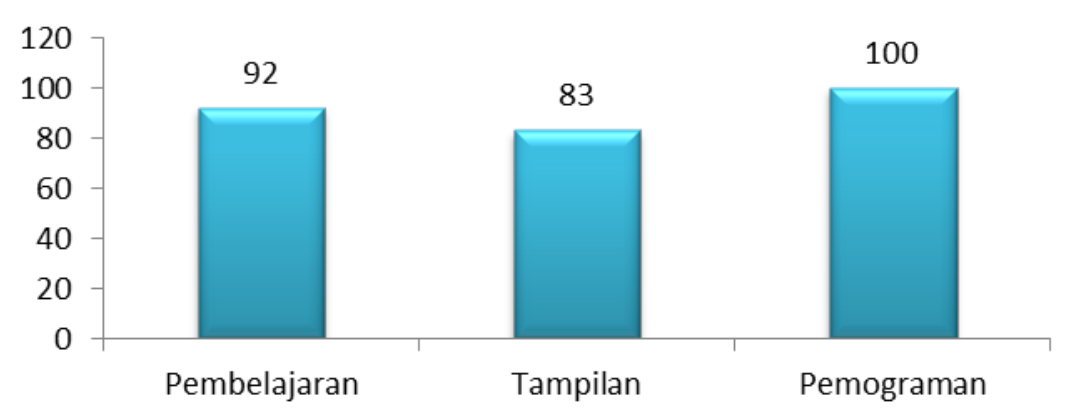

Gambar 8. Hasil Angket Respon Peserta Didik

Dari grafik dapat dinyatakan bahwa aspek pemograman mendapatkan rata-rata skor tertinggi, sedangkan aspek tampilan mendapatkan skor terendah. Berdasarkan hasil angket respon peserta didik tersebut dapat disimpulkan bahwa media pembelajaran berbasis ICT menggunakan macromedia flash pada mata pelajaran IPA Kelas IV SD/MI sangat praktis.

2. Uji efektivitas

Uji efektivitas dilakukan dengan memberikan tes atau evaluasi terhadap peserta didik ketika mereka telah mengikuti kegiatan pembelajaran dengan menggunakan media yang dikembangkan. Tes atau evaluasi ini dilakukan untuk mengetahui efektivitas media pembelajaran IPA 
berbasis ICT dengan menggunakan macromedia flash terhadap tujuan pembelajaran yang telah ditetapkan melalui hasil belajar yang diperoleh. Adapun hasil belajar peserta didik yang dimaksud meliputi aspek pada ranah kognitif, afektif, dan psikomotorik pada 17 orang peserta didik . Total Hasil belajar peserta didik tersebut dapat dilihat pada tabel 5 dan gambar 9.

Tabel 5. Hasil Belajar Peserta Didik

\begin{tabular}{cccccc}
\hline $\begin{array}{c}\text { Peserta } \\
\text { didik }\end{array}$ & Kognitif & $\begin{array}{c}\text { Aspek Nilai } \\
\text { Afektif }\end{array}$ & Psikomotorik & $\begin{array}{c}\text { Nilai } \\
\text { Hasil } \\
\text { Belajar }\end{array}$ & Keterangan \\
1 & 90 & 90 & 90 & 90 & Tuntas \\
2 & 90 & 85 & 80 & 85 & Tuntas \\
3 & 80 & 80 & 85 & 81 & Tuntas \\
4 & 100 & 85 & 80 & 88 & Tuntas \\
5 & 75 & 75 & 80 & 76 & Tuntas \\
6 & 75 & 80 & 75 & 76 & Tuntas \\
7 & 80 & 80 & 85 & 81 & Tuntas \\
8 & 85 & 85 & 80 & 83 & Tuntas \\
9 & 95 & 80 & 90 & 88 & Tuntas \\
10 & 95 & 80 & 85 & 86 & Tuntas \\
11 & 85 & 90 & 80 & 85 & Tuntas \\
12 & 80 & 85 & 80 & 81 & Tuntas \\
13 & 80 & 75 & 75 & 76 & Tuntas \\
14 & 80 & 80 & 80 & 80 & Tuntas \\
15 & 100 & 90 & 85 & 91 & Tuntas \\
16 & 90 & 85 & 80 & 85 & Tuntas \\
17 & 95 & 90 & 90 & 91 & Tuntas \\
Jumlah & $\mathbf{1 4 7 5}$ & $\mathbf{1 4 1 5}$ & $\mathbf{1 4 0 0}$ & $\mathbf{1 4 2 3}$ & $\mathbf{1 7}$ \\
Rata- & $\mathbf{8 6 , 7 6}$ & $\mathbf{8 3 , 2 3}$ & $\mathbf{8 2 , 3 5}$ & $\mathbf{8 3 , 7 0}$ & $\mathbf{1 0 0 \%}$ \\
rata & & & & & \\
\hline
\end{tabular}




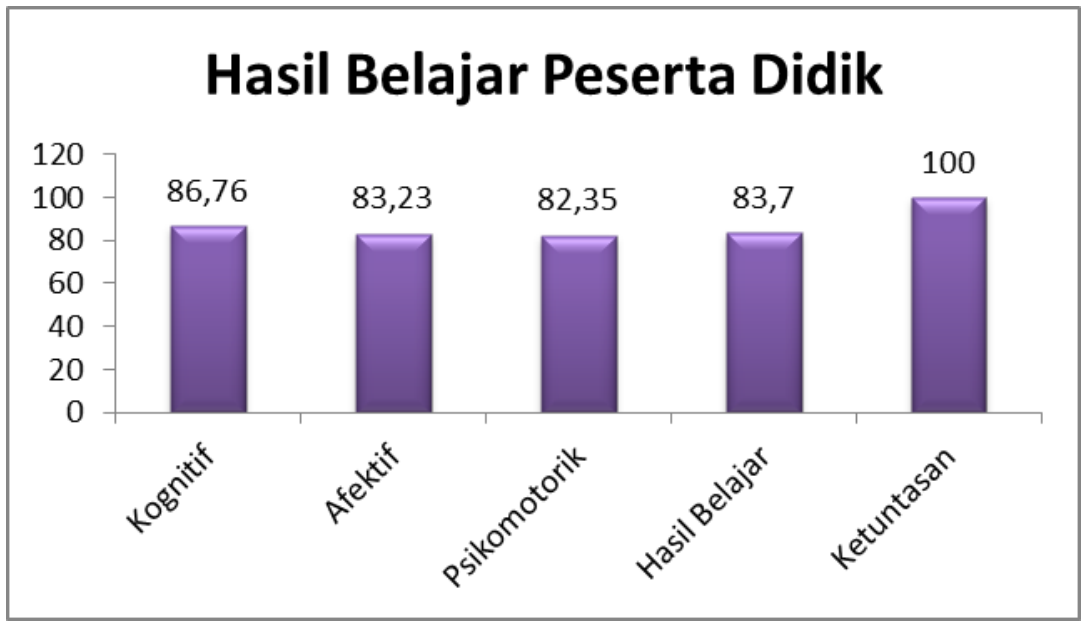

Gambar 9. Hasil Belajar Peserta Didik

Dari data yang diperoleh dapat diketahui bahwa ketuntasan belajar secara klasikal dapat tercapai secara maksimal. Hal tersebut ditunjukkan dengan tercapainya Nilai KKM Mata Pelajaran IPA di Kelas IV MI Assegaf Palembang sebesar $100 \%$ atau seluruh peserta didik yang berjumlah 17 telah mencapai nilai ketuntasan minimal Mata Pelajaran IPA. Beradasarkan pencapaian nilai KKM tersebut, maka dapat disimpulkan bahwa media pembelajaran berbasis ICT menggunakan macromedia flash pada Mata Pelajaran IPA Kelas IV SD/MI sangat efektif dalam mencapai hasil belajar peserta didik. Keaadan ini sesuai dengan pernyataan Warsita di mana ia menyatakan bahwa efektifnya suatu kegiatan apabila kegiatan yang dilakukan tersebut dapat diselesaikan pada waktu yang tepat dan tujuan yang diinginkan tercapai. Selain itu efektivitas juga menekankan pada perbandingan antara suatu rencana yang telah disusun dengan tujuan yang akan dicapai. Oleh sebab itu, efektivitas suatu proses pembelajaran sering kali dilihat dari tercapainnya tujuan pembelajaran. Kemudian efektivitas juga didefenisikan sebagai ketepatan dalam mengelola suatu situasi. ${ }^{15}$

${ }^{15}$ Bambang Warsita, Teknologi Pembelajaran: Landasan dan Aplikasinya, Jakarta, Rineka Cipta, 2008, h. 287 
AL-MUDARRIS:journal of education, Vol. 2. No. 1 April 2019, ISSN: 2620-5831 (print), ISSN: 2620-4355(online)

DOI: 10.32478/al-mudarris.v2i1.194

\section{KESIMPULAN}

Berdasarkan data dan pembahasan yang telah dijelasakn oleh peneliti, maka dapat kesimpulan penelitian ini adalah sebagai berikut:

1. Perancangan atau desain media pembelajaran berbasis ICT menggunakan macromedia flash pada mata pelajaran IPA Kelas IV SD/MI dalam proses pengembangannya menggunakan model four-D (4-D) models, yaitu definition, design, develop, dan dessiminate. Dari proses pengembangan dengan model tersebut menghasilkan rancangan atau desain media pembelajaran berbasis ICT menggunakan macromedia flash pada mata pelajaran IPA di Kelas IV SD/MI yang terdiri dari halaman depan, tentang media, silabus, materi (teks, video, latihan), dan tes.

2. Tingkat kepraktisan penerapan media pembelajaran berbasis ICT menggunakan macromedia flash pada mata pelajaran IPA Kelas IV SD/MI sangat praktis. Hasil tersebut diperoleh dari uji kepraktisan responden guru dan uji kepraktisan responden peserta didik. Angket respon guru diperoleh jumlah skor total 70 dengan total rata-rata skor 87,5. Angket respon peserta didik diperoleh jumlah skor total 154 dengan total ratarata skor 90,58 .

3. Efektifitas penerapan media pembelajaran berbasis ICT menggunakan macromedia flash pada mata pelajaran IPA Kelas IV SD/MI MI sangat efektif dalam mencapai hasil belajar peserta didik. Hal tersebut ditunjukkan dengan perolehan nilai secara klasikal, yaitu: 1) aspek kognitif mendapatkan junlah 1475 dan rata-rata 86,76 dengan kategori baik; 2) aspek afektif mendapatkan jumlah 1415 dan rata-rata 83,23 dengan kategori baik; 3) aspek psikomotorik mendapatkan jumlah 1400 dan rata-rata 82,35 dengan kategori baik. Dari hasil akumulasi ketiga aspek penilaian tersebut diperoleh jumlah 1423 dan rata-rata 83,70 dengan kategori baik. Selanjutnya dari data nilai seluruh peserta didik yang 
AL-MUDARRIS:journal of education, Vol. 2. No. 1 April 2019, ISSN: 2620-5831 (print), ISSN: 2620-4355(online)

DOI:

berjumlah 17 juga diketahui telah mencapai nilai ketuntasan minimal Mata Pelajaran IPA sebesar $100 \%$ dengan kategori sangat efektif.

\section{DAFTAR PUSTAKA}

A. Muhson. 2010. Pengembangan Media Pembelajaran Berbasis Teknologi Informasi. Jurnal Pendidikan Akuntansi Indonesia. Volume 8. Nomor 2.

A. Suryadi. 2007. Pemanfaatan ICT dalam Pembelajaran. Jurnal Pendidikan Terbuka dan Jarak Jauh. Volume 8. Nomor 1.

A. Z. Rahman. T. N. Hidayat. dan I. Yanuttama. 2017. Media Pembelajaran IPA Kelas 3 Sekolah Dasar Menggunakan Teknologi Augmented Reality Berbasis Android. Seminar Nasional Teknologi Informasi dan Multimedia. Maret. Volume 5. Nomor 1.

Andi Prastowo. 2014. Pengembangan Bahan Ajar Tematik Tinjauan Teoretis dan Praktik. Jakarta. Kencana.

Bambang Warsita. 2008. Teknologi Pembelajaran: Landasan dan Aplikasinya. Jakarta. Rineka Cipta.

R. Zainiah dan T. Rijanto. 2016. Pengembangan Media Pembelajaran Berbasis Animasi dan Simulasi untuk Meningkatkan Hasil Belajar Peserta didik pada Mapel Instalasi Penerangan Listrik di SMKN 1 Sidoarjo. Volume 5. Nomor 2.

Sugiyono. 2008. Metode Penelitian Pendidikan Pendekatan Kuantitatif. Kualitatif. dan R\&D. Bandung. Alfabeta.

T. Aprilia. Sunardi. dan Djono. 2017. Pemanfaatan Media Buku Digital Berbasis Kontekstual dalam Pembelajaran IPA dalam "Pemanfaatan Smartphone untuk Literasi Produktif Menjadi Guru Hebat dengan Smartphone". Pascasarjana Teknologi Pendidikan FKIP Universitas Sebelas. Maret.

Trianto. 2007. Mendesain Model Pembelajaran InovatifProgresif: Konsep. Landasan. dan Implementasinya pada Kurikulum Tingkat Satuan Pendidikan (KTSP). Jakarta. Kencana Prenada Media Group. 2010. h. 189; 
AL-MUDARRIS:journal of education, Vol. 2. No. 1 April 2019, ISSN: 2620-5831 (print), ISSN: 2620-4355(online)

DOI: 10.32478/al-mudarris.v2i1.194

Trianto. Model Pembelajaran Terpadu dalam Teori dan Praktek. Jakarta. Prestasi Pustaka.

Trianto. 2010. Model Pembelajaran Terpadu. Jakarta. Bumi Aksara.

Wina Sanjaya. 2008. Perencanaan dan Desain Sistem Pembelajaran. Jakarta. Prenadamedia Group.

Yulianto, 'KONSEP PENDIDIKAN ANAK DALAM PERSPEKTIF IBNU HAJAR AL- HAITAMI (Ragam Eksplorasi Kitab Tahrīru Al-Maqōl Fī Adābi Wa Ahkāmi Wa Fawā'idu Yahtāju Ilaihā Mu addibū Al-Aṭ̂al)', AL-MUDARRIS: Journal of Education, 1 (2018),39-54

<https://doi.org/http://dx.doi.org/10.32478/almudarris.v1i1.98> 